\title{
下水污泥溶融スラグのコンクリート用粗骨材 への適用性打よび品質に関する研究
}

\author{
井上真 澄* Carlos Aquino ** \\ 武田字 浦*** 岡 本享 久****
}

\section{A Study on the Application and Quality of Sewage Sludge Molten Slag Coarse Aggregate for Concrete}

by

\author{
Masumi Inoue ${ }^{*}$, Carlos Aquino ${ }^{* *}$, Naho TAKedA ${ }^{* * *}$ and Takahisa OкAмото ${ }^{* * * *}$
}

\begin{abstract}
This study was carried out to examine the application of sewage sludge molten slag as coarse aggregate for concrete and the influence of the quality of molten slag on the mechanical properties of concrete. As a result, it was clarified that the mechanical properties of concrete by using molten slag coarse aggregate depended on the quality of molten slag. The concrete by using molten slag coarse aggregate which was good strength had performance equivalent to normal aggregate concrete. In the quality standard of molten slag for concrete, it is necessary to provide not only the density and water absorption but also the standard related to the strength of aggregate.
\end{abstract}

Key words : Sewage sludge molten slag, Coarse aggregate, Strength, Freeze-thaw resistance, Crushing value, Percentage of abrasion

\section{1 緒言}

コンクリートにおいて骨材は約 7 割以上の体積を占め, フレッシュコンクリートの性状や硬化コンクリートの物 性に影響を及ぼす要因として広く認識されている。骨材 としては，これまで全国各地に豊富に存在した川砂利や 川砂が古くから使用されてきたが，近年環境保全に係る 問題や資源の有効利用といった課題に直面し，再生骨材 や副産物を起源とする骨材の有効利用に向けた取り組み が活発となっている。

一方，近年の下水道普及率の向上に伴い，下水污泥の 発生量が全国規模で年々増加傾向にある。下水污泥は, 下水処理後に発生する污泥を粘土状（ケーキ状）に脱水 処理したものであり，産業廃棄物として埋立て処理され ているのが現状である。しかし，残余年数が逼迫する最 終処分場への負荷を軽減するためにも，下水污泥の減量 化あるいは資源化が望まれている。そうした状況に対応 して, 最終処分量を減らすために溶融固化設備が導入さ れてきた。

溶融固化設備より排出される下水污泥溶融スラグ（以 下, 溶融スラグと称す) を有効利用することは, 最終処分 場の延命策の一つとして有効である. 同時にコンクリート 用骨材として様々な用途に利用することが可能となれば， 資源の枯渇や骨材採取に伴う環境破壊の抑制にもつなが
り，その意義は非常に大きい。近年，下水污泥や廃棄物 を起源とした溶融スラグの骨材への適用性については多 方面で研究開発 1) 6) されて抢り，2006 年にはコンクリー 卜用骨材として JIS A 5031 （一般廃棄物，下水污泥又は それらの焼却灰を溶融固化したコンクリート用溶融スラ グ骨材）が制定されている.

溶融スラグをコンクリート用粗骨材として使用した場 合には, 非晶質の溶融スラグを用いるとコンクリートの 強度や耐久性が著しく低下する. ${ }^{1)}$ 一方で, 結晶化した溶 融スラグであれば普通砕石コンクリートと同等以上の強 度を発揮する ${ }^{3)}$, 4)など，溶融スラグの品質がコンクリー トの強度や耐久性に及ぼす影響は大きいと考えられる。し かし, その溶融スラグの品質の違いがコンクリートとして の物理的性質に与える影響について詳細な検討を行った 研究成果は見当たらない。また，現在の JIS には，溶融 スラグ粗骨材の品質規定值として密度, 吸水率, 安定性 などが挙げられているが, その他にも骨材強度やセメン トペースト界面の付着性状などの影響も無視できないと 考えられ，溶融スラグ粗骨材の品質基準の最適化が望ま れる。

本研究では，下水污泥溶融スラグの粗骨材への適用に 着目し，その品質がコンクリートの強度や耐久性に与え る影響を実験的に検討した。これにより，溶融スラグ粗

\footnotetext{
$\dagger$ 原稿受理 平成 22 年 11 月 8 日 Received Nov. 8, 2010 C 2011 The Society of Materials Science, Japan

* 正 会 員 北見工業大学工学部社会環境工学科 广090-8507 北見市公園町, Dept. of Civil and Env. Eng., Kitami Inst. of Tech., Koencho, Kitami, 090-8507

** 立命館大学大学院理工学研究科＝525-8577 草津市野路東, Graduate School of Sci. and Eng., Ritsumeikan Univ., Nojihigashi, Kusatsu, 525-8577

*** 正 会 員 明石工業高等専門学校都市システム工学科 †674-8501 明石市魚住町, Dept. of Civil Eng., Akashi National College of Tech., Uozumicho, Akashi, 674-8501

**** 正 会 員 立命館大学理工学部環境システム工学科 †525-8577 草津市野路東, Dept. of Env. Systems Eng., Ritsumeikan Univ., Nojihigashi, Kusatsu, 525-8577
} 
Table 1 Mechanical properties of sewage sludge molten slag coarse aggregates.

\begin{tabular}{|c|c|c|c|c|c|c|c|c|c|c|}
\hline $\begin{array}{c}\text { Series } \\
\text { (Slag) }\end{array}$ & $\begin{array}{c}\text { Melting } \\
\text { solidification } \\
\text { facility }\end{array}$ & $\begin{array}{c}\text { Surface-dry } \\
\text { density } \\
\left(\mathrm{g} / \mathrm{cm}^{3}\right)\end{array}$ & $\begin{array}{c}\text { Absolute-dry } \\
\text { density } \\
\left(\mathrm{g} / \mathrm{cm}^{3}\right)\end{array}$ & $\begin{array}{c}\text { Fineness } \\
\text { modulus }\end{array}$ & $\begin{array}{c}\text { Water } \\
\text { absorption } \\
(\%)\end{array}$ & $\begin{array}{c}\text { Bulk } \\
\text { density } \\
(\mathrm{kg} / \mathrm{l})\end{array}$ & $\begin{array}{c}\text { Solid } \\
\text { content } \\
(\%)\end{array}$ & $\begin{array}{c}\text { Soundness } \\
(\%)\end{array}$ & $\begin{array}{c}\text { Percentage } \\
\text { of abrasion } \\
(\%)\end{array}$ & $\begin{array}{c}\text { Crushing } \\
\text { value } \\
(\%)\end{array}$ \\
\hline I & A & 2.65 & 2.60 & 6.52 & 2.16 & 1.52 & 58.5 & 0.7 & 43.6 & 41.1 \\
\hline II & B & 2.48 & 2.44 & 6.57 & 0.69 & 1.41 & 57.4 & 1.7 & 28.2 & 22.7 \\
\hline III & B & 2.64 & 2.60 & 6.52 & 0.90 & 1.45 & 57.0 & 0.3 & 23.6 & 21.5 \\
\hline \multicolumn{2}{|r|}{ Standard-1 ${ }^{* 1}$} & - & $\geqq 2.50$ & - & $\leqq 3.00$ & - & - & $\leqq 12$ & - & - \\
\hline \multicolumn{2}{|r|}{ Standard-2 } & - & $\geqq 2.50$ & - & $\leqq 3.00$ & - & $\geqq 55.0$ & $\leqq 12$ & $\leqq 40.0$ & - \\
\hline
\end{tabular}

Note $; * 1:$ JIS A 5031 (Melt-solidified slag aggregate for concrete derived from municipal solid waste and sewage sludge) $* 2$ : JIS A 5005 (crushed stone and sand for concrete aggregate) $* 3$ : British Standard. B.S. 812

骨材の品質とコンクリートの性能との関係が明確となり， 溶融スラグ粗骨材の品質基準の最適化や溶融スラグの更 なる有効利用促進に向けた資料となり得る結果が得られ たことから，これを報告する。

\section{2 実 験 概 要}

\section{$2 \cdot 1$ 下水污泥溶融スラグ粗骨材}

本研究では, 3 種類の溶融スラグを研究対象とした。 溶融スラグは，滋賀県内の 2 つの溶融固化施設 $(\mathrm{A} \cdot \mathrm{B})$ から製造された空冷スラグである。いずれの空冷スラグ も，污泥ケーキを流動床式焼却炉および旋回式溶融炉に より $1400 \sim 1450^{\circ} \mathrm{C}$ で加熱溶融し自然冷却したものであ る。その後，粉砕して $5 \sim 20 \mathrm{~mm}$ に粒度調整したものを 使用した。

Fig. 1 には各溶融スラグの粒子の写真を示す．スラグ I は，A施設において製造されたものであり，ガラス質の 光沢が目立ち，粒子表面は平滑で凹凸が少ないことがわ かる。一方，スラグ II と III は，B施設において製造さ れたものであり，粒子表面に凹凸が見られ，外見上は砕 石に類似している。また，スラグ II は，他の溶融スラグ に比較して, 粒子表面に多くの気泡を含んでいることが わかる。このように同じ下水污泥を起源とした溶融スラ グであっても，溶融固化施設が異なることや溶融温度等 運転状況により溶融スラグの外観も異なる。

Table 1 に溶融スラグ粗骨材の物理的性質と JIS 規格 值を示す。表中の破砕值については，英国規格 B.S.812 に準じ，粒径 15 ～10mm に調整した乾燥試料を用いて測 定した。スラグ I と III は，絶乾密度が $2.60 \mathrm{~g} / \mathrm{cm}^{3}$ と JIS 規格を満足しているのに対して，スラグ II は $2.44 \mathrm{~g} / \mathrm{cm}^{3}$ と JIS 規格を下回っている。吸水率は，スラグ I が最も 大きいが JIS の規格值は満足した。一方，すりへり減量 や破砕值については，スラグIがいずれも最も大きな值 を示しており，骨材強度が他の溶融スラグよりも低い。

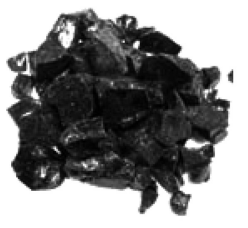

Slag I

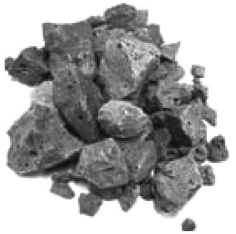

Slag II

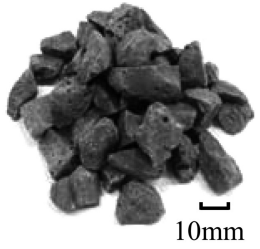

Slag III
Fig. 1 Sewage sludge molten slag coarse aggregate.
スラグ I は，前述のように外見上もガラス質であること がこれを裏付けている。その他，化学法によるアルカリ シリカ反応性は全溶融スラグで無害，モルタル膨張率試 験においても同じく基準值を満足していた。

Fig. 2 に各種溶融スラグ粗骨材の粒度分布を示す。各 溶融スラグは若干粒度が小さい傾向にあるが，概ねコン クリート用砕石の粒度規格を満たした。

Table 2 に化学成分を示す. JIS A 5031 には，コンク リートに有害な影響を与えるものとして, 酸化カルシウム $(\mathrm{CaO})$, 全硫黄 $(\mathrm{S})$, 三酸化硫黄 $\left(\mathrm{SO}_{3}\right)$, 金属鉄 $(\mathrm{Fe})$, 塩化物量 $(\mathrm{NaCl})$ が挙げられている. 本研究で対象とし た溶融スラグは，全項目にて規定值を下回っており，化 学的に安全な溶融スラグと評価できる。

Table 3 に溶融スラグからの有害物質の溶出量を, Table 4 に有害物質の含有量を示す.JIS A 5031 では, 環境庁告示第 46 号「土壤の污染に係る環境基準につい て」と同等の規定を定めている．溶出量および含有量と もに，すべての項目について土壤基準值以下であり，本 研究で対象とする溶融スラグは安全であると評価できる.

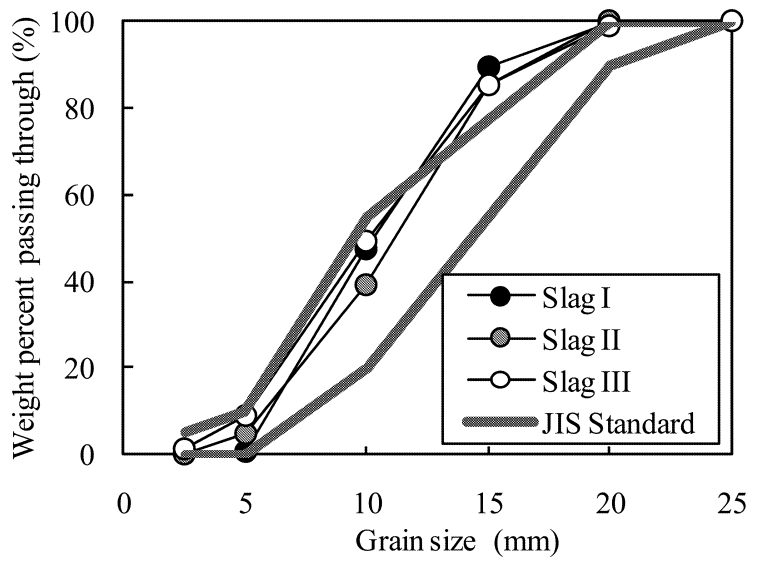

Fig. 2 Grain size distribution of molten slag coarse aggregate.

Table 2 Chemical composition of molten slag.

\begin{tabular}{|c|c|c|c|c|}
\hline Item & Slag I & Slag II & Slag III & JIS standard \\
\hline $\mathrm{CaO}(\%)$ & 17.6 & 21.7 & 17.4 & $\leqq 45$ \\
\hline $\mathrm{S}(\%)$ & 0.03 & 0.03 & 0.03 & $\leqq 2.0$ \\
\hline $\mathrm{SO}_{3}(\%)$ & 0.07 & $<0.1$ & $<0.1$ & $\leqq 0.5$ \\
\hline $\mathrm{Fe}(\%)$ & $<0.1$ & $<0.1$ & $<0.1$ & $\leqq 1.0$ \\
\hline $\mathrm{NaCl}(\%)$ & $<0.01$ & $<0.001$ & $<0.001$ & $\leqq 0.04$ \\
\hline
\end{tabular}


Table 3 Results of organic matter elution test.

\begin{tabular}{|c|c|c|c|c|}
\hline Item & Slag I & Slag II & Slag III & JIS standard \\
\hline $\mathrm{Cd}(\mathrm{mg} / \mathrm{L})$ & $<0.001$ & $<0.001$ & $<0.001$ & $\leqq 0.01$ \\
\hline $\mathrm{Pb}(\mathrm{mg} / \mathrm{L})$ & $<0.005$ & $<0.001$ & $<0.001$ & $\leqq 0.01$ \\
\hline $\mathrm{Cr}^{6+}(\mathrm{mg} / \mathrm{L})$ & $<0.02$ & $<0.005$ & $<0.005$ & $\leqq 0.05$ \\
\hline $\mathrm{As}(\mathrm{mg} / \mathrm{L})$ & $<0.005$ & 0.006 & 0.007 & $\leqq 0.01$ \\
\hline $\mathrm{Hg}(\mathrm{mg} / \mathrm{L})$ & $<0.0005$ & $<0.0005$ & $<0.0005$ & $\leqq 0.0005$ \\
\hline $\mathrm{Se}(\mathrm{mg} / \mathrm{L})$ & $<0.001$ & $<0.001$ & $<0.001$ & $\leqq 0.01$ \\
\hline $\mathrm{F}(\mathrm{mg} / \mathrm{L})$ & $<0.09$ & $<0.1$ & $<0.1$ & $\leqq 0.8$ \\
\hline $\mathrm{B}(\mathrm{mg} / \mathrm{L})$ & $<0.1$ & $<0.1$ & $<0.1$ & $\leqq 1.0$ \\
\hline
\end{tabular}

Note ; Test method : JIS K 0058-1
Table 4 Results of organic matter content test.

\begin{tabular}{|c|c|c|c|c|}
\hline Item & Slag I & Slag II & Slag III & JIS standard \\
\hline $\mathrm{Cd}(\mathrm{mg} / \mathrm{kg})$ & 0.75 & $<1$ & $<1$ & $\leqq 150$ \\
\hline $\mathrm{Pb}(\mathrm{mg} / \mathrm{kg})$ & 32 & 19 & 17 & $\leqq 150$ \\
\hline $\mathrm{Cr}^{6+}(\mathrm{mg} / \mathrm{kg})$ & $<2$ & $<1$ & $<1$ & $\leqq 250$ \\
\hline $\mathrm{As}(\mathrm{mg} / \mathrm{kg})$ & 10.8 & 5 & 7 & $\leqq 150$ \\
\hline $\mathrm{Hg}(\mathrm{mg} / \mathrm{kg})$ & $<0.02$ & $<0.1$ & $<0.1$ & $\leqq 15$ \\
\hline $\mathrm{Se}(\mathrm{mg} / \mathrm{kg})$ & $<0.2$ & $<1$ & $<1$ & $\leqq 150$ \\
\hline $\mathrm{F}(\mathrm{mg} / \mathrm{kg})$ & 52 & 78 & 35 & $\leqq 4000$ \\
\hline $\mathrm{B}(\mathrm{mg} / \mathrm{kg})$ & 91 & 32 & 22 & $\leqq 4000$ \\
\hline
\end{tabular}

Note ; Test method : JIS K 0058-2

Table 5 Mechanical properties of aggregates (except for molten slag).

\begin{tabular}{|c|c|c|c|c|c|c|c|c|c|c|}
\hline & $\begin{array}{l}\text { Series } \\
\text { (Slag) }\end{array}$ & & $\begin{array}{c}\text { Surface-dry } \\
\text { density } \\
\left(\mathrm{g} / \mathrm{cm}^{3}\right)\end{array}$ & $\begin{array}{c}\text { Absolute-dry } \\
\text { density } \\
\left(\mathrm{g} / \mathrm{cm}^{3}\right)\end{array}$ & $\begin{array}{l}\text { Fineness } \\
\text { modulus }\end{array}$ & $\begin{array}{c}\text { Water } \\
\text { absorption } \\
(\%)\end{array}$ & $\begin{array}{c}\text { Bulk } \\
\text { density } \\
(\mathrm{kg} / \mathrm{l})\end{array}$ & $\begin{array}{c}\text { Solid } \\
\text { content } \\
(\%)\end{array}$ & $\begin{array}{c}\text { Percentage } \\
\text { of abrasion } \\
(\%)\end{array}$ & $\begin{array}{c}\text { Crushing } \\
\text { value } \\
(\%)\end{array}$ \\
\hline \multirow{3}{*}{$\begin{array}{c}\text { Fine } \\
\text { aggregate }\end{array}$} & I & River sand & 2.60 & 2.56 & 2.73 & 1.56 & 1.65 & 64.5 & - & - \\
\hline & II & \multirow{2}{*}{$\begin{array}{c}\text { Crushed } \\
\text { sand }\end{array}$} & 2.62 & 2.57 & 2.78 & 2.10 & 1.66 & 64.7 & - & - \\
\hline & III & & 2.64 & 2.60 & 2.75 & 2.00 & 1.66 & 63.9 & - & - \\
\hline \multirow{3}{*}{$\begin{array}{c}\text { Coarse } \\
\text { aggregate }\end{array}$} & I & \multirow{3}{*}{$\begin{array}{l}\text { Crushed } \\
\text { stone }\end{array}$} & 2.70 & 2.68 & 6.80 & 0.70 & 1.61 & 60.1 & 11.4 & 15.1 \\
\hline & II & & 2.67 & 2.65 & 6.74 & 0.62 & 1.58 & 59.1 & 9.8 & 9.0 \\
\hline & III & & 2.64 & 2.62 & 6.75 & 1.26 & 1.59 & 60.8 & 11.2 & 10.4 \\
\hline
\end{tabular}

Table 6 Mix proportions for concrete.

\begin{tabular}{|c|c|c|c|c|c|c|c|c|c|c|c|c|c|}
\hline \multirow{2}{*}{$\begin{array}{l}\text { Series } \\
\text { (Slag) }\end{array}$} & \multirow{2}{*}{ Symbol } & \multirow{2}{*}{$\begin{array}{l}\mathrm{W} / \mathrm{C} \\
(\%)\end{array}$} & \multirow{2}{*}{$\begin{array}{c}\begin{array}{c}\text { Slag content } \\
(\%)\end{array} \\
\end{array}$} & \multirow{2}{*}{$\begin{array}{l}\mathrm{s} / \mathrm{a} \\
(\%)\end{array}$} & \multicolumn{5}{|c|}{ Unit weight $\left(\mathrm{kg} / \mathrm{m}^{3}\right)$} & \multirow{2}{*}{$\begin{array}{c}\mathrm{Ad}_{1} \\
\left(\mathrm{ml} / \mathrm{m}^{3}\right)\end{array}$} & \multirow{2}{*}{$\begin{array}{c}\mathrm{Ad}_{2} \\
\left(\mathrm{ml} / \mathrm{m}^{3}\right)\end{array}$} & \multirow{2}{*}{$\begin{array}{l}\text { Slump } \\
(\mathrm{cm})\end{array}$} & \multirow{2}{*}{$\begin{array}{l}\text { Air } \\
(\%)\end{array}$} \\
\hline & & & & & $\mathrm{W}$ & $\mathrm{C}$ & $\mathrm{S}$ & $\mathrm{G}$ & $\mathrm{MG}$ & & & & \\
\hline \multirow{5}{*}{ I } & $50-0$ & \multirow{5}{*}{50} & 0 & \multirow{5}{*}{44.0} & \multirow{5}{*}{167} & \multirow{5}{*}{334} & \multirow{5}{*}{780} & 927 & 0 & 835 & 1336 & 8.0 & 5.5 \\
\hline & $50-25$ & & 25 & & & & & 695 & 223 & 835 & 1336 & 8.5 & 4.6 \\
\hline & $50-50$ & & 50 & & & & & 463 & 446 & 752 & 1202 & 7.0 & 4.3 \\
\hline & $50-75$ & & 75 & & & & & 232 & 669 & 668 & 668 & 8.0 & 4.7 \\
\hline & \begin{tabular}{|l|}
$50-100$ \\
\end{tabular} & & 100 & & & & & 0 & 892 & 585 & 0 & 6.5 & 3.8 \\
\hline \multirow{4}{*}{ II } & $50-0$ & \multirow{4}{*}{50} & 0 & \multirow{4}{*}{44.7} & \multirow{4}{*}{176} & \multirow{4}{*}{352} & \multirow{4}{*}{782} & 986 & 0 & 1126 & 2253 & 6.5 & 3.6 \\
\hline & $50-30$ & & 30 & & & & & 690 & 275 & 1126 & 1760 & 7.0 & 5.1 \\
\hline & $50-50$ & & 50 & & & & & 492 & 458 & 1056 & 1408 & 7.0 & 4.0 \\
\hline & \begin{tabular}{|l|}
$50-100$ \\
\end{tabular} & & 100 & & & & & 0 & 916 & 1760 & 0 & 7.0 & 6.0 \\
\hline \multirow{4}{*}{ III } & $55-0$ & \multirow{4}{*}{55} & 0 & \multirow{4}{*}{45.0} & \multirow{4}{*}{175} & \multirow{4}{*}{318} & \multirow{4}{*}{807} & 986 & 0 & 636 & 1591 & 9.5 & 5.6 \\
\hline & $55-25$ & & 25 & & & & & 740 & 247 & 636 & 1591 & 9.5 & 5.8 \\
\hline & $55-50$ & & 50 & & & & & 493 & 493 & 795 & 1591 & 8.0 & 4.4 \\
\hline & \begin{tabular}{|l|}
$55-100$ \\
\end{tabular} & & 100 & & & & & 0 & 986 & 986 & 1591 & 8.0 & 4.5 \\
\hline
\end{tabular}

Note; $\mathrm{Ad}_{2}$ is $1 \%$ solution.

\section{$2 \cdot 2$ 使用材料}

本実験における検討は，溶融スラグの種類別に 3 つの シリーズから構成される。セメント[C]には全シリーズに おいて，普通ポルトランドセメント（密度： $3.16 \mathrm{~g} / \mathrm{cm}^{3}$ ) を使用した. Table 5 に各シリーズにおいて使用した骨 材（溶融スラグ以外）の物性值を示す。全シリーズとも 基準とする粗骨材は砂岩砕石 2005 とした，細骨材につい ては，シリーズ I では川砂を，シリーズ II と III では砂岩 砕砂を使用した。混和剤には全シリーズにおいて， $\mathrm{AE}$ 減 水剂 $\left[\mathrm{Ad}_{1}\right]$ （密度 : $1.10 \mathrm{~g} / \mathrm{cm}^{3}$, 主成分：リグニンスルホ ン酸化合物）と $\mathrm{AE}$ 助剂 $\left[\mathrm{Ad}_{2}\right]$ （密度 $: 1.19 \mathrm{~g} / \mathrm{cm}^{3}$, 主成 分：アルキルアリルスルホン酸化合物）を使用した.

\section{$2 \cdot 3$ コンクリートの配合}

Table 6 にコンクリートの配合を示す．本実験では， 普通強度コンクリートを対象として配合を決定した。ス ラグ I を用いたシリーズ I では水セメント比を $50 \%$ ，溶融 スラグの置換率 (容積比，以下ではスラグ置換率と称す) を 0，25，50，75，100\%の 5 水準，スラグ II を用いたシ
リーズ II では水セメント比を 50\%，スラグ置換率を 0，30， 50，100\%の 4 水準，スラグIIIを用いたシリーズ III では 水セメント比を 55\%，スラグ置換率は 0，25，50，100\% の 4 水準とした。全配合で目標スランプは $7.5 \pm 2 \mathrm{~cm}$, 空 気量は $4.5 \pm 1 \%$ とし，混和剂により調整した。

\section{$2 \cdot 4$ 試験項目}

Table 7 に試験項目を示す. フレッシュコンクリート のスランプ，空気量はJIS に準拠して行った。コンクリー 卜供試体は，打設後材齢 1 日で脱型し，所定の試験材齢

Table 7 Test items.

\begin{tabular}{|c|c|c|}
\hline Test & JIS & Size of specimen \\
\hline Slump & JIS A 1101 & - \\
\hline Air & JIS A 1128 & - \\
\hline Compressive strength & JIS A 1108 & $\phi 100 \times 200 \mathrm{~mm}$ \\
\hline Modulus of rupture & JIS A 1106 & $100 \times 100 \times 400 \mathrm{~mm}$ \\
\hline Tensile strength & JIS A 1113 & $\phi 150 \times 150 \mathrm{~mm}$ \\
\hline Modulus of elasticity & JIS A 1149 & $\phi 100 \times 200 \mathrm{~mm}$ \\
\hline Freezing and thawing & JIS A 1148 & $100 \times 100 \times 400 \mathrm{~mm}$ \\
\hline
\end{tabular}


まで水中養生 $\left(20 \pm 1^{\circ} \mathrm{C}\right)$ を行った。硬化コンクリートの 各種試験は, JIS に準拠して行った。凍結融解試験は, 供試体を材齢 28 日まで水中養生 $\left(20 \pm 1^{\circ} \mathrm{C}\right)$ を行った後, 300 サイクルまで外観観察, 質量減少率, 動弾性係数の 測定を行った。

\section{3 実験結果および考察}

\section{$3 \cdot 1$ 各種強度および静弾性係数}

Table 8 に各種強度試験打よび静弾性係数試験結果を 示す．また，Fig. 3 には強度比打よび静弾性係数比とス ラグ置換率の関係を示す. 強度比打よび静弾性係数比と は，スラグ無置換の普通コンクリートの強度および静弾 性係数を 1 としたものである.

スラグ I ではスラグ置換率の増加に伴って, 各種強度 や静弾性係数が明確に低下する傾向を示している，材齢 28 日の圧縮強度で最大 $15 \%$ の強度低下, 曲げ強度扎よ び割裂引張強度では最大 $25 \%$ 程度の強度低下を示した。 スラグIは，密度や吸水率は JIS 規定值を十分に満足す るが，その外観が示すようにガラス質で骨材強度が低い ことがコンクリートの強度低下を招いた原因と考えられ る。特に, 曲げ強度と割裂引張強度での強度低下率が大 きいのは, 溶融スラグ単体の強度特性だけでなく, 溶融 スラグ表面が平滑であるためセメントペーストとの付着 性状が悪いことが影響していると考えられる.
一方，スラグ II および III については，スラグ I とは 傾向が異なり, 各種強度はスラグ置換率 $0 \%$ に比較して 同等以上の強度発現が得られた。特にスラグ II は，密度 が小さく JIS 規定値を満足していないにも関わらず，材 齢 28 日の圧縮強度で最大 $13 \%$ の強度增加, 曲げ強度と 割裂引張強度では最大 $20 \%$ 程度の強度増加を示した。

静弾性係数については, 各種強度が示す強度変化とは 若干傾向が異なる，各種強度面では良好なデータを示し たスラグII において，スラグ置換率 $0 \%$ に対して最大 $12 \%$ 低下した。スラグ II は，その外観に打いて骨材粒子表面 に数多くの気泡を含んでいることを確認している。密度 も低い值を示していることから内部にも多くの気泡を含 有していると考えられ，骨材単体のひずみ量が大きかっ たことによるものと推察される.

\section{$3 \cdot 2$ 凍結融解抵抗性}

Fig. 4 に相対動弾性係数の経時変化を示す．スラグ I では，スラグ置換率の増加に伴い，相対動弾性係数が低 下する傾向にある，スラグ置換率 100\%では，相対動弾 性係数が $70 \%$ を下回った。これは，スラグ I の吸水率が 大きく, 溶融スラグの置換率の増加に伴い凍結可能水量 が増加したこと，および溶融スラグ単体の骨材強度が低 いことが原因と考えられる。一方のスラグ II および III に损いては，スラグ置換率の増加に伴う相対動弾性係数

Table 8 Compressive strength, tensile strength, flexural strength and modulus of elasticity.

\begin{tabular}{|c|c|c|c|c|c|c|c|c|c|}
\hline \multirow{2}{*}{$\begin{array}{l}\text { Series } \\
\text { (Slag) }\end{array}$} & \multirow{2}{*}{ Symbol } & \multirow{2}{*}{$\begin{array}{l}\mathrm{W} / \mathrm{C} \\
(\%)\end{array}$} & \multirow{2}{*}{$\begin{array}{c}\text { Slag } \\
\text { Content } \\
(\%) \\
\end{array}$} & \multicolumn{3}{|c|}{ Compressive strength $\left(\mathrm{N} / \mathrm{mm}^{2}\right)$} & \multirow{2}{*}{$\begin{array}{c}\text { Tensile } \\
\text { strength } \\
f_{t 28}\left(\mathrm{~N} / \mathrm{mm}^{2}\right)\end{array}$} & \multirow{2}{*}{$\begin{array}{c}\text { Bending } \\
\text { strength } \\
f_{b 28}\left(\mathrm{~N} / \mathrm{mm}^{2}\right)\end{array}$} & \multirow{2}{*}{$\begin{array}{c}\text { Modulus of } \\
\text { elasticity } \\
E_{c 28}\left(\mathrm{kN} / \mathrm{mm}^{2}\right)\end{array}$} \\
\hline & & & & $f_{c 7}^{\prime}$ (7days) & $f_{c 28}^{\prime}(28$ days $)$ & $f_{c 91}^{\prime}(91$ days $)$ & & & \\
\hline \multirow{5}{*}{ I } & $50-0$ & \multirow{5}{*}{50} & 0 & $31.5[1.00]$ & $42.6[1.00]$ & $47.4[1.00]$ & $3.21[1.00]$ & $5.83[1.00]$ & $31.8[1.00]$ \\
\hline & $50-25$ & & 25 & $29.2[0.93]$ & $39.8[0.93]$ & $44.8[0.95]$ & $3.26[1.02]$ & $5.35[0.92]$ & $31.1[0.98]$ \\
\hline & $50-50$ & & 50 & $27.7[0.88]$ & $37.4[0.88]$ & $41.5[0.87]$ & $2.57[0.80]$ & $4.57[0.78]$ & $31.5[0.99]$ \\
\hline & $50-75$ & & 75 & $26.9[0.85]$ & $36.2[0.85]$ & $40.8[0.86]$ & $2.36[0.74]$ & $4.36[0.75]$ & $28.5[0.90]$ \\
\hline & $50-100$ & & 100 & $26.9[0.85]$ & $39.5[0.93]$ & $45.8[0.97]$ & $2.74[0.85]$ & $4.44[0.76]$ & $31.3[0.98]$ \\
\hline \multirow{4}{*}{ II } & $50-0$ & \multirow{4}{*}{50} & 0 & $35.8[1.00]$ & $43.4[1.00]$ & $49.0[1.00]$ & $3.55[1.00]$ & $5.61[1.00]$ & $34.8[1.00]$ \\
\hline & $50-30$ & & 30 & $37.7[1.05]$ & $42.9[0.99]$ & $49.4[1.01]$ & $3.69[1.04]$ & $5.62[1.00]$ & $32.1[0.92]$ \\
\hline & $50-50$ & & 50 & $36.9[1.03]$ & $43.9[1.01]$ & $51.6[1.05]$ & $3.84[1.08]$ & $6.85[1.22]$ & $30.5[0.88]$ \\
\hline & $50-100$ & & 100 & $41.1[1.15]$ & $49.0[1.13]$ & $53.8[1.10]$ & $4.26[1.20]$ & $6.78[1.21]$ & $34.4[0.99]$ \\
\hline \multirow{4}{*}{ III } & $55-0$ & \multirow{4}{*}{55} & 0 & $27.9[1.00]$ & $34.5[1.00]$ & $35.2[1.00]$ & $3.00[1.00]$ & $5.45[1.00]$ & $23.5[1.00]$ \\
\hline & $55-25$ & & 25 & $26.3[0.94]$ & $35.4[1.03]$ & - & $3.16[1.05]$ & $5.71[1.05]$ & $23.6[1.01]$ \\
\hline & $55-50$ & & 50 & $26.6[0.95]$ & $35.8[1.04]$ & 36.5 [1.04] & $2.95[0.98]$ & $5.90[1.08]$ & $25.2[1.07]$ \\
\hline & $55-100$ & & 100 & $27.4[0.98]$ & $36.2[1.05]$ & $39.4[1.12]$ & $3.36[1.12]$ & $5.99[1.10]$ & $27.6[1.18]$ \\
\hline
\end{tabular}

Note ; [ ] : Strength and modulus of elasticity ratio to normal concrete
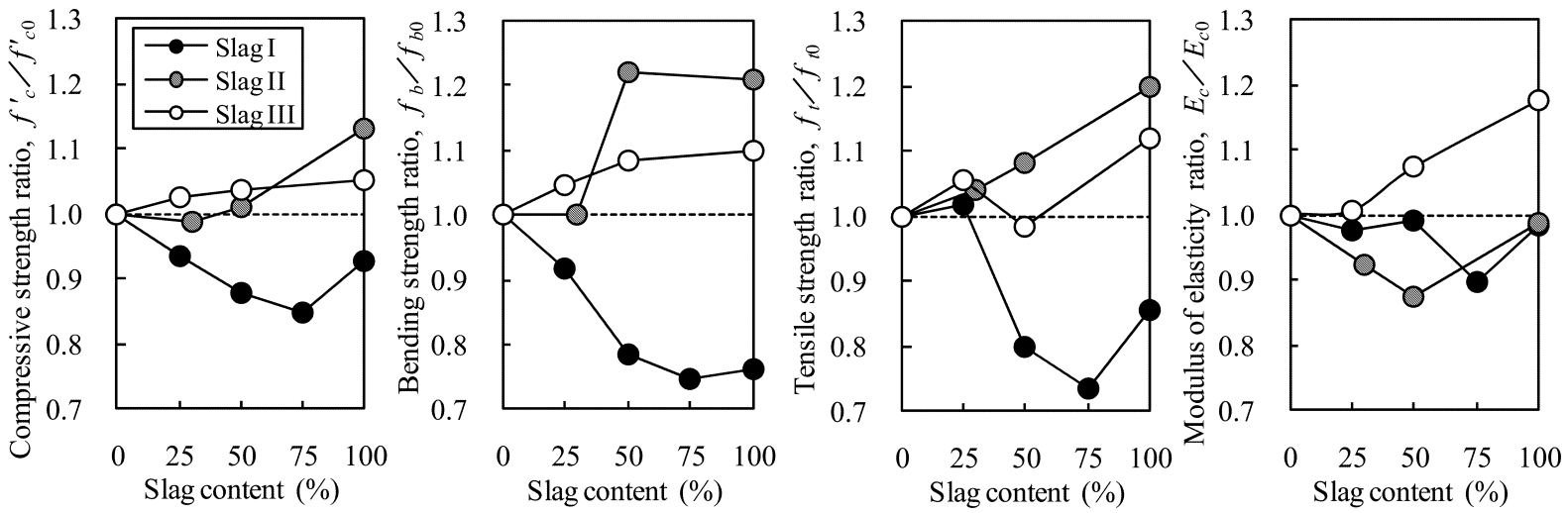

Fig. 3 Strength and modulus of elasticity ratio to normal concrete (28days). 

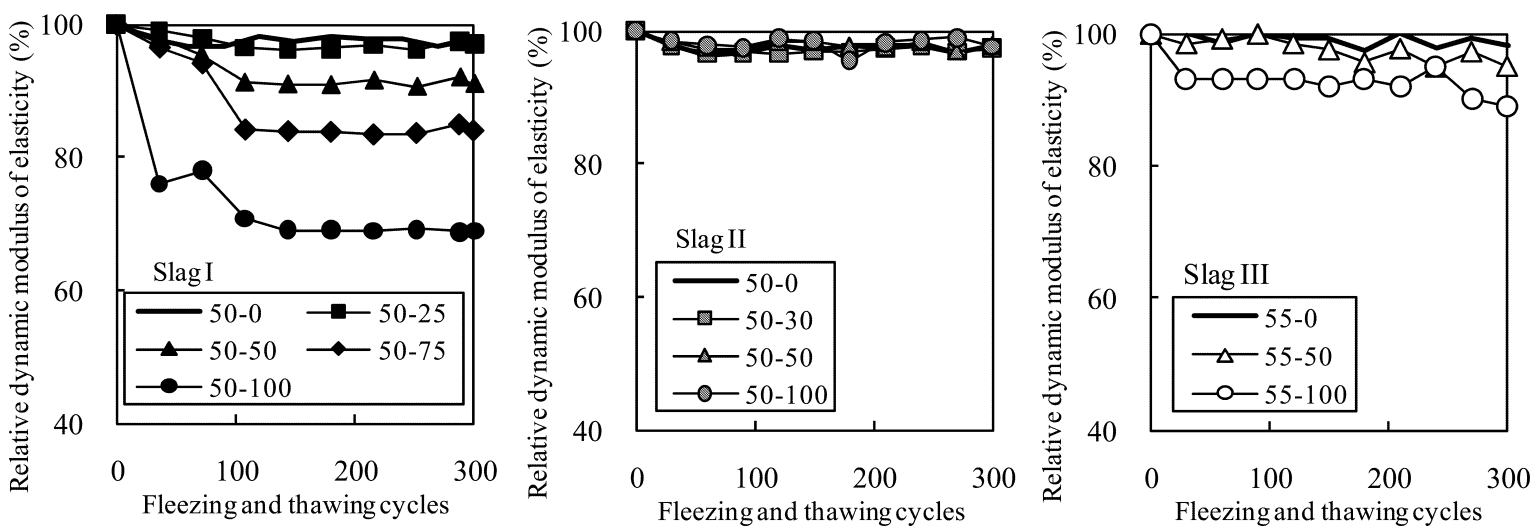

Fig. 4 Results of freezing and thawing test.
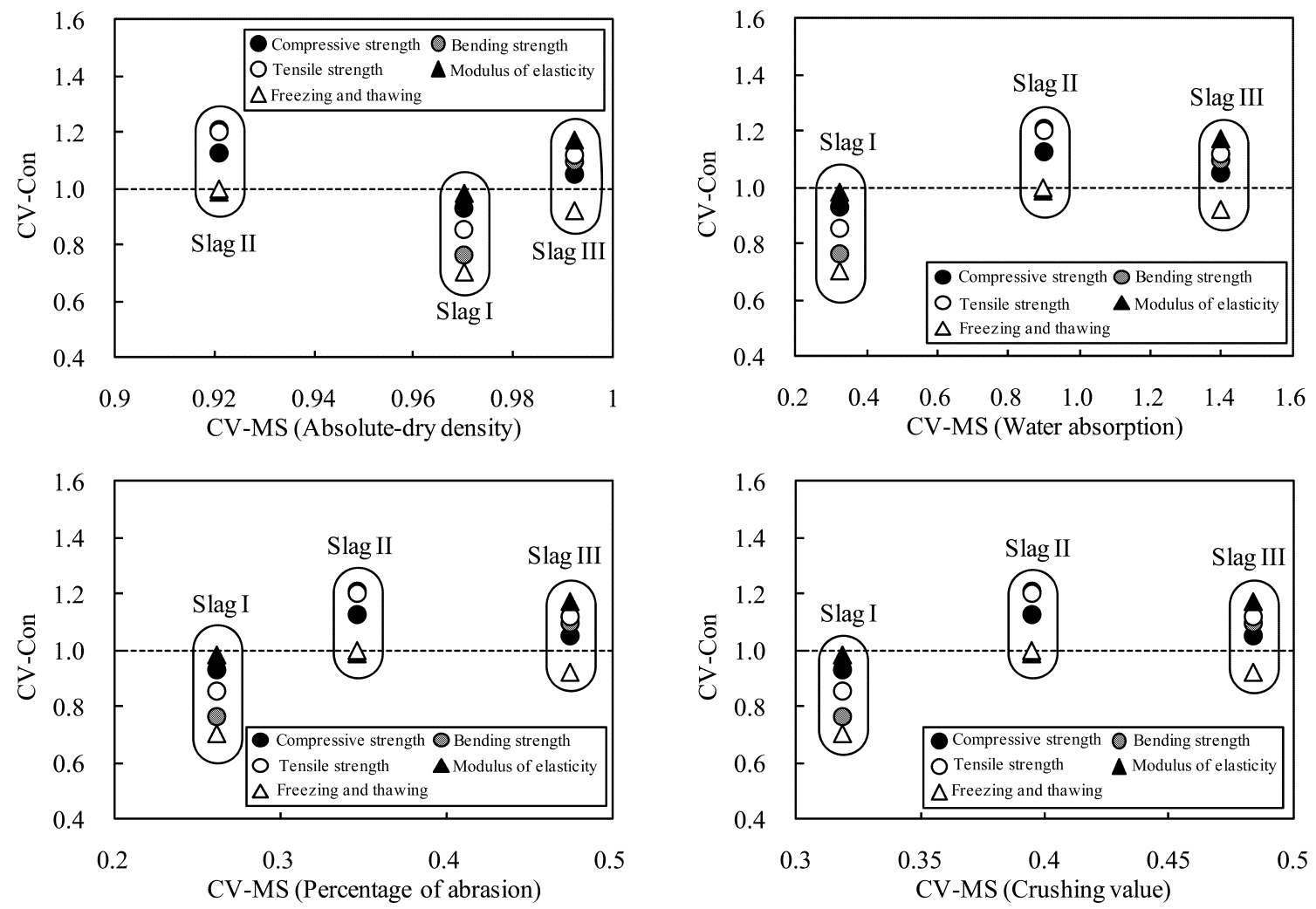

Fig. 5 Relationship between CV-Con and CV-MS.

の低下は小さいものであり，溶融スラグを $100 \%$ 置換し た場合であっても 300 サイクルまで $90 \%$ 以上の相対動弾 性係数を示した。

\section{$3 \cdot 3$ 溶融スラグの品質に関する評価}

溶融スラグ粗骨材を用いたコンクリートの力学的特性 に関する検討より，溶融スラグの物理的性質がコンクリー トの強度や耐久性に及ぼす影響は大きいことが明らかと なった。また，溶融スラグ単体の骨材強度に優れるスラ グ II や III を使用した場合には, 砕石を用いた普通コン クリートと同等以上の性能を有していた。ここでは，溶 融スラグ粗骨材の各種特性と溶融スラグ粗骨材を用いた コンクリートの各種性能との関係について詳細な検討を 行い，溶融スラグ粗骨材の品質指標の最適化について考 察を行った。

Fig. 5 に溶融スラグを用いたコンクリートの各種性能
值と溶融スラグの各種性能值の関係を示す。ここで，コ ンクリートの性能值 (CV-Con : Characteristic Value of Concrete) とは，粗骨材に砕石を使用したコンクリート （以下，基準コンクリートと称す）の実験值（材齢 28 日） を各種性能の基準值として，溶融スラグ粗骨材を $100 \%$ 置換したコンクリートの実験值（材齢 28 日）を相対的 に換算した数值である。例えば，コンクリートの引張強 度 $f_{t 28}$ の性能值 CV-Con- $f_{t 28}$ は以下の式で計算した。

CV-Con- $f_{t 28}=f_{t 28-100 \%} / f_{t 28-0 \%}$

ここで, $f_{t 28-100 \%}$ は溶融スラグ $100 \%$ 置換コンクリートの引 張強度, $f_{t 28-0 \%}$ は基準コンクリートの引張強度である. スラ グII を用いたコンクリートの場合, Table 8 より $f_{t 28-100 \%}=$ $4.26 \mathrm{~N} / \mathrm{mm}^{2}, f_{t 28-0 \%}=3.55 \mathrm{~N} / \mathrm{mm}^{2}$ であるから，性能值は 1.20 となる。

一方, 溶融スラグの性能值 (CV-MS：Characteristic 
Value of Molten Slag) とは, Table 5 に示す砕石の各種物 性值を基準として，Table 1 に示す溶融スラグの物性值を 相対的に換算した数值である，例えば，溶融スラグの絶 乾密度 $\rho$ に関する性能值 (CV-MS- $\rho$ ) は次式で計算した。

$$
\text { CV-Con }-\rho=\rho_{M S} / \rho_{C S}
$$

ここで， $\rho_{M S}$ は溶融スラグの絶乾密度， $\rho_{C S}$ は砕石の絶乾 密度である，スラグ II の場合, Table 1 より $\rho_{M S}=2.44 \mathrm{~g} /$ $\mathrm{cm}^{3}$, Table 5 より $\rho_{C S}=2.65 \mathrm{~g} / \mathrm{cm}^{3}$ であるから, 性能值 は 0.92 となる。なお，溶融スラグの吸水率，すりへり減 量および破砕值に関する性能值については，換算した数 值の逆数をとった。したがって，コンクリートおよび溶 融スラグの全性能值は，その值が高いものほど高品質で あることを意味する。

一般に骨材の品質指標として使用されている絶乾密度 や吸水率は，コンクリートの強度や耐久性との相関が高 いと考えられるが，本実験で対象とした 3 種類の溶融ス ラグに関しては絶乾密度とのその相関は認められない. Fig. 5 に示すスラグ II の場合，溶融スラグの絶乾密度に 関する性能值が低い，すなわち骨材密度が小さい溶融ス ラグであってもコンクリートの性能值は概ね 1.0 以上と 良好な值を示している。逆にスラグ I では絶乾密度の性 能值が 0.92 と砂岩砕石と同等の絶乾密度を有しながらコ ンクリートの性能值はすべて 1.0 を下回っており, 強度 および耐久性が低下している。

一方，すりへり減量打よび破砕值の性能值に着目する と，若干の変動はあるものの性能值が高まることによっ て，コンクリートの各種性能值も高まる傾向が認められ る。スラグ II と III を比較した場合には，すりへり減量 および破砕值に差異はあるものの，コンクリートの各種 性能值はスラグ III の凍結融解抵抗性を除けばいずれも概 ね 1.0 以上を示しており，基準コンクリートと同等以上 の性能を有している。これは，コンクリート用粗骨材と して溶融スラグの適用性を判断する指標として, 密度や 吸水率よりもすりへり減量や破砕值による評価が適する ことを示している。したがって，基準コンクリートと同 等以上の性能が得られたスラグ II および III の物理的性 質（Table 2 参照）から，すりへり減量で $28 \%$ 以下，破 砕值で $22 \%$ 以下といった骨材性状に関する共通条件は, 溶融スラグを対象とした密度打よび吸水率を補う品質指 標の目安として評価できると考えられる。

以上から，溶融スラグ粗骨材を用いたコンクリートの 諸性能と溶融スラグの諸性能には関係が認められるとと もに，溶融スラグの特性を考慮した品質指標と基準值の 必要性が伺える。コンクリートとしての性能を踏まえた 溶融スラグの品質指標として，特に骨材強度に関する特 性の把握が重要であると考えられる。

\section{4 結言}

本研究では，下水污泥溶融スラグの粗骨材への適用に 着目し，その品質がコンクリートの強度や耐久性に与え る影響を実験的に検討した。
以下に，本研究で得られた結果をまとめる.

（1）溶融スラグ粗骨材の物理的性質がコンクリートの 各種強度打よび耐久性に及ぼす影響は大きい。

（2）骨材強度に優れる溶融スラグを粗骨材として使用 したコンクリートは，砕砂砕石を使用した普通コンクリー トと同等以上の性能を有していた。

（3）溶融スラグのコンクリート用粗骨材としての品質 管理や評価に関しては，単に密度や吸水率だけに依存す るのではなく, 骨材の強度に関係する品質指標の設置が 必要である。

本研究から, 溶融スラグの物理的性質として, 骨材強 度に起因する品質がコンクリートの性能に大きく影響し ていることが明らかとなった。 今後は，溶融スラグの品 質管理基準に関する究明と具現化が緊急の課題である. 同時に，その品質指標をもとに溶融スラグをクラス分け し，クラス毎の適用範囲や最適なスラグ置換率を検討し ていくことが溶融スラグの有効利用拡大に向けて重要で あると考えている。

\section{参 考 文 献}

1) K. Nemoto and Y. Hara, "Molten slag as aggregate", Proceedings of the Annual Conference of the Japan Society of Waste Management Experts, Vol.9, No.1, pp.436-439 (1998).

2) M. Kitatsuji and K. Fujii, "Properties of concrete using melting slag form municipal solid waste as fine aggregate", Transactions of the Japan society of irrigation, drainage and rural engineering, No.200, pp.59-67 (1999).

3 ) T. Saito, K. Nishida, J. Mochizuki and Y. Nara, "Effects of crystallized domestic waste slag recycled aggregate on concrete properties", Proceedings of the Japan concrete institute, Vol.22, No.2, pp.289-295 (2000).

$4)$ T. Saito, Y. Hara, H. Yoda, K. Nishida, J. Mochizuki and Y. Nara, "Experimental study on properties of concrete made of molten slag aggregate frome domestic waste", AIJ Journal of technology and design, No.15, pp.5-10 (2002).

$5)$ T. Saito, H. Sato, N. Taniyama, A. Nemoto and H. Ikenaga, "Study on properties of concrete using surface-modified molten slag fine aggregate originated from domestic wastes", Journal of structural and construction engineering, No.589, pp.1-6 (2005).

6 ) Y. Sagawa, Y. Kawabata, H. Matsushita, J. Miyake and S. Hirai, "A study on utilization of molten slag of municipal solid waste as fine aggregate for concrete", Journal of Japan society of civil engineers, No.802/V-69, pp.171-180 (2005).

7 ) T. Matsuka, K. Sakai, W. Nishigori, T. Yokoyama, Y. Nishimoto and S. Onodera, "Effect of rubbing- reformation in application of various molten slag to concrete", Journal of Japan society of civil engineers, Vol.62, No.1, pp.174-185 (2006). 